\title{
DIFFERENTIATED THYROID CANCER IN PEDIATRIC POPULATION ( $\leq 18$ YEARS): POSTOPERATIVE TREATMENT WITH RADIOACTIVE IODINE (I-131)
}

\author{
Marin Prpić ${ }^{1}$, Maja Franceschii ${ }^{1,2,3}$,Tomislav Jukić ${ }^{1,2,3}$, Davor Kust ${ }^{1}$, Nina Dabelić ${ }^{1}$, \\ Tea Varjačić ${ }^{1}$, Marko Lucijanić ${ }^{4}$, Ante Bolanča ${ }^{1}$ and Zvonko Kusićc 5 \\ ${ }^{1}$ Department of Oncology and Nuclear Medicine, Sestre milosrdnice University Hospital Centre, \\ Zagreb, Croatia; ${ }^{2}$ School of Medicine, University of Zagreb, Zagreb, Croatia; ${ }^{3}$ Faculty of Medicine, \\ Josip Juraj Strossmayer University of Osijek, Osijek, Croatia; ${ }^{4}$ Department of Hematology, \\ Dubrava University Hospital, Zagreb, Croatia; ${ }^{5}$ Croatian Academy of Sciences and Arts, Zagreb, Croatia; \\ ${ }^{6}$ Aviva Polyclinic, Zagreb, Croatia
}

\begin{abstract}
SUMMARY - The aim is to present data on the treatment and follow-up in a cohort of patients with pediatric thyroid cancer who underwent total thyroidectomy and received postoperative radioactive iodine (I-131) therapy. The study was conducted in a tertiary high-volume thyroid center, in pediatric patients with differentiated thyroid cancer who were consecutively treated during the 19652015 period. A total of 45 patients aged $\leq 18$ years having undergone total thyroidectomy with or without selective neck dissection were included in the study. Decision on postoperative I-131 ablation was based on tumor characteristics, postoperative thyroglobulin level, preablative whole body scintigraphy, and/or neck ultrasound. Median age at diagnosis was 15 years. The presence of cervical lymph node metastases was significantly associated with papillary thyroid cancer, larger tumor size, involvement of two thyroid lobes, and multifocal disease. The presence of distant metastases was significantly associated with larger tumor size. None of the patients died during follow-up period, and the 5-year and 10 -year overall survival rates were $100 \%$. The 5 -year and 10 -year progression-free survival (PFS) rates were $87 \%$ and $73 \%$, respectively. Male gender $(\mathrm{p}=0.046)$, age $\leq 15$ years $(\mathrm{p}=0.029)$ and tumor size $>15 \mathrm{~mm}(\mathrm{p}=0.042)$ were significantly associated with inferior PFS. A significant positive trend of increase in the number of newly diagnosed patients was observed over time $(p=0.011)$. Clinical management of pediatric thyroid cancer is challenging, especially in the light of increasing incidence in this population. Male patients younger than 15 years and with tumors of more than $15 \mathrm{~mm}$ in size require additional caution due to lower PFS observed.
\end{abstract}

Key words: Iodine; Thyroid cancer, papillary; Adenocarcinoma, follicular; Survival rate; Child; Follow-up studies

\section{Introduction}

While thyroid cancer is the most common endocrine tumor in adults, it is much less frequent in chil-

Correspondence to: Maja Franceschi, MD, Department of Oncology and Nuclear Medicine, Sestre milosrdnice University Hospital Centre, Vinogradska c. 29, HR-10000 Zagreb, Croatia

E-mail: maja.franceschi@gmail.com

Received September 5, 2017, accepted October 2, 2017 dren and adolescents, accounting for $1.8 \%$ of all differentiated thyroid cancer (DTC) cases $^{1,2}$. DTC is generally more advanced at the time of diagnosis in children and adolescents than in adults, with neck lymph node metastasis and distant metastasis (mostly in lungs) occurring in 39\%-90\% and 6\%-41\% of patients, respectively ${ }^{3-6}$. Despite advanced stage at diagnosis and high recurrence rate (11\%-45\%), the prognosis of pediatric thyroid cancer is more favorable than 
in adults, with only sporadic cases with fatal outcomes (less than $5 \%)^{7-10}$. As survival rates suggest, thyroid cancer in children and adolescents is genetically different from the adult type, with important clinical, molecular and pathologic divergences, which could prove to be a contributing factor in treatment efficacy9. Current standard of care for these patients is surgery (total thyroidectomy $)^{11}$. Application rate of postoperative treatment with radioactive iodine (I-131) varies among centers, but is generally becoming more common in the treatment of pediatric patients ${ }^{12}$. Studies regarding I-131 therapy in children are limited and mostly of low-level evidence, especially in the adjuvant setting ${ }^{13}$. Furthermore, there are no established standardized activities of I-131 for the pediatric population, and these are usually determined based on the individual physician's decision, especially in patients with disseminated disease ${ }^{10}$. Children and adolescents with thyroid cancer are shown to have better progression-free survival (PFS) after I-131 therapy than adult patients, thus it is necessary to assess the potential risk/benefit ratio prior to the application of therapy ${ }^{5,8}$. In the frame of larger proportion of patients with pediatric DTC that receive high activities of I-131 and long overall survival (OS), issues have arisen regarding long-term adverse effects, with particular accent on the development of secondary malignancies. Here we present clinicopathologic data on 45 pediatric patients treated with I-131 for thyroid cancer collected over a 50-year period.

\section{Patients and Methods}

The study was conducted in a tertiary high-volume thyroid center, based on data on all pediatric patients with DTC that were evaluated between 1965 and 2015. Inclusion criteria were as follows: $\leq 18$ years of age at diagnosis; and diagnosis of DTC confirmed by histopathologic analysis (total thyroidectomy or lobectomy). There were no additional exclusion criteria, and a total of 45 patients were included in the study. The study was conducted in compliance with ethical standards set by the institutional Ethics Committee and the Helsinki Declaration from 1975, as revised in 1983. Decisions with respect to postoperative I-131 ablation were based on histopathologic tumor characteristics, postoperative thyroglobulin ( $\mathrm{Tg}$ ) level, postoperative anti-Tg antibody ( $\mathrm{TgAb})$ level, preablative whole body scintigraphy (WBS), and/or neck ultra- sound. Neck ultrasound was performed in all patients after the introduction of the method in 1978, and preablative WBS was selectively performed to estimate the mass of the possible thyroid remnant after surgery. Postoperative WBS was done in all patients that received I-131 therapy. Multiple I-131 therapies were administered in cases of ablation failure, defined as the presence of remnant thyroid tissue (visible accumulation of I-131) in the thyroid bed and cervical region on WBS ( $\mathrm{Tg}$ level, TgAb level, and neck ultrasound were used as additional diagnostic criteria). $\mathrm{Pa}-$ tients were regularly followed-up for disease recurrence and dissemination at 6- to 12 -month intervals, until the study cut-off date on December 31, 2016.

All procedures performed in studies involving human participants were in accordance with ethical standards set by the institutional and/or national research committee and with the 1964 Helsinki Declaration and its later amendments or comparable ethical standards.

\section{Statistical analysis}

The normality of distribution of numerical variables was tested using the Shapiro-Wilk test. Numerical variables were presented as median and interquartile range (IQR), and categorical variables were presented as number and percentage. Numerical variables between groups were compared using the Mann Whitney $\mathrm{U}$ test and categorical variables were compared between groups using the $\chi^{2}$-test. Spearman rank correlation was used to test correlation between numerical variables. Poisson regression was used to test the trend of increase in the number of cases over time. Survival analyses were performed using the methods of Kaplan and Meier and the Cox-Mantel log-rank test ${ }^{14}$. Cut-off point for numerical variables was determined using ROC curve analysis. Data were screened using custom made MS Excel workbook ${ }^{15}$ and re-analyzed using MedCalc Statistical Software version 16.2.0 (MedCalc Software bvba, Ostend, Belgium). The values of $\mathrm{p}<0.05$ were considered significant. Optimal cut-off points for transforming numerical variables into dichotomous variables for the purpose of survival analysis were determined using ROC curve analysis with PFS status as a classification variable. Age $>15$ years and tumor size $>15 \mathrm{~mm}$ showed best survival discriminatory properties. 
Table 1. Characteristics of pediatric patients with differentiated thyroid cancer at the time of diagnosis $(N=45)$

\begin{tabular}{|l|l|}
\hline Category & Number (\%) \\
\hline Histologic diagnosisa: & $39 / 43(91)$ \\
Papillary thyroid cancer & $4 / 43(9)$ \\
Follicular thyroid cancer & \\
Capsule infiltration ${ }^{\mathrm{b}}:$ & $7 / 23(30.4)$ \\
$\quad$ Present & $16 / 23(69.6)$ \\
Absent & \\
Lobe involvementc: & $19 / 28(67.9)$ \\
Unilobular tumor & $9 / 28(32.1)$ \\
Both lobes involved & \\
Focal tumor distribution ${ }^{\text {d: }}$ & $19 / 29(65.5)$ \\
Unifocal disease & $10 / 29(34.5)$ \\
Multinodal disease & \\
Cervical lymph node involvement & \\
Present & $23 / 39(59)$ \\
Absent & $16 / 39(41)$ \\
Distant metastases at diagnosisf: & \\
Total & $6 / 42(14.3)$ \\
Lungs only & $4 / 42(9.5)$ \\
Lungs and bones & $2 / 42(4.8)$ \\
No metastasis & $36 / 42(85.7)$ \\
\hline
\end{tabular}

Number of patients with unknown status: a2; ${ }^{\mathrm{b}} 22$; ${ }^{\mathrm{c}} 17$; ${ }^{\mathrm{d}} 16$; ${ }^{\mathrm{e}} 6$; ${ }^{\mathrm{f}} 3$

\section{Results}

\section{Patient characteristics}

A total of 45 pediatric patients with DTC were evaluated, representing $1.5 \%$ of all patients in DTC database. Median age at diagnosis was 15 years, IQR 13-16. There were 40 (89\%) female and five (11\%) male patients, yielding a female to male ratio of 8:1. Patient characteristics are shown in Tables 1-3. The number of patients diagnosed with DTC was stable until the last decade, when a substantial increase in the number of newly diagnosed cases was observed. Overall, there was a significant positive trend of increase in the number of newly diagnosed patients over time $(\mathrm{p}=0.011)$, as shown in Figure 1. Patients were further divided into tertiles of the study period to analyze whether outcomes differed in patients treated in different time periods. We observed no significant difference in outcomes between these patient groups $(\mathrm{p}=0.432)$, as shown in Figure 2. While the majority of patients received I-131 (91\%), the applied activity and number of applications varied, reflecting tumor specific features that guided therapeutic approach. Median total I-131 activity was $3700 \mathrm{MBq}(100 \mathrm{mCi})$ (IQR 65-209), and median number of applications was 1 (IQR 1-2). Median postoperative Tg was $19.4 \mathrm{ng} / \mathrm{mL}$ (IQR 13.6-68).

Table 2. Tumor features in patients with or without lymph node (LN) metastases

\begin{tabular}{|l|l|l|l|}
\hline & Without LN involvement & With LN involvement & p value \\
\hline Number of patients & 16 & 23 & - \\
PTC diagnosis & $12 / 16(75 \%)$ & $23 / 23(100 \%)$ & 0.022 \\
Age (yrs) & $15.5 \mathrm{IQR}(14-16)$ & $14 \mathrm{IQR}(13-16.5)$ & 0.443 \\
Male gender & 0/16 (0\%) & $4 / 23(17.4 \%)$ & 0.130 \\
Tumor size (mm) & $15 \mathrm{IQR}(9-22)$ & $26 \mathrm{IQR}(18.8-33.5)$ & 0.028 \\
Capsule infiltration & $1 / 9(11.1 \%)$ & $6 / 13(46.2 \%)$ & 0.165 \\
Involvement of both lobes & $1 / 12(8.3 \%)$ & $7 / 15(46.7 \%)$ & 0.043 \\
Multinodal thyroid disease & $1 / 12(8.3 \%)$ & $8 / 16(50 \%)$ & 0.039 \\
Distant metastases & /115(0\%) & $6 / 23(26.1 \%)$ & 0.063 \\
Postoperative Tg & $68.7 \mathrm{IQR}(44.1-93.4)$ & $13.6 \mathrm{IQR}(8.8-40.8)$ & 0.248 \\
Patients receiving I ${ }^{131}$ & $13 / 14(92.9 \%)$ & $22 / 23(95.7 \%)$ & 1.000 \\
Total RAI activity & $99.5 \mathrm{IQR}(55-161.8)$ & $150 \mathrm{IQR}(100-258.5)$ & 0.064 \\
Number of applications & $1 \mathrm{IQR}(1-1.8)$ & $2 \mathrm{IQR}(1-2)$ & 0.146 \\
Overall survival & $100 \%$ & $100 \%$ & - \\
5-year PFS & $85.9 \%$ & $84.6 \%$ & 0.620 \\
\hline
\end{tabular}

$\mathrm{PTC}=$ papillary thyroid cancer $\mathrm{Tg}=$ thyroglobulin; $\mathrm{RAI}=$ radioiodine therapy $\mathrm{PFS}=$ progression free survival; $\mathrm{IQR}=$ interquartile range 
Table 3. Tumor features in patients with and without distant metastases

\begin{tabular}{|l|l|l|l|}
\hline & Without distant metastases & With distant metastases & $\mathrm{p}$ value \\
\hline Number of patients & 36 & 6 & - \\
\hline PTC diagnosis & $31 / 35(88.6 \%)$ & $6 / 6(100 \%)$ & 1.000 \\
\hline Age (yrs) & $15 \mathrm{IQR}(13.8-16)$ & $15 \mathrm{IQR}(13.3-16.8)$ & 0.913 \\
\hline Female gender & $33 / 36(91.7 \%)$ & $5 / 6(83.3 \%)$ & 0.474 \\
\hline Tumor size (mm) & $20 \mathrm{IQR}(10-24.3)$ & $50 \mathrm{IQR}(44.8-51.3)$ & 0.002 \\
\hline Capsule infiltration & $5 / 20(25 \%)$ & $2 / 2(100 \%)$ & 0.091 \\
\hline Involvement of both lobes & $7 / 24(29.2 \%)$ & $2 / 4(50 \%)$ & 0.574 \\
\hline Multinodal thyroid disease & $8 / 25(32 \%)$ & $2 / 4(50 \%)$ & 0.592 \\
\hline Cervical lymph node involvement & $17 / 32(53.1 \%)$ & $6 / 6(100 \%)$ & 0.063 \\
\hline Postoperative Tg & $43.7 \mathrm{IQR}(15.5-80.5)$ & $13.6 \mathrm{IQR}(13.6-13.6)$ & 0.480 \\
\hline Patients receiving I-131 & $32 / 35(91.4 \%)$ & $6 / 6(100 \%)$ & 1.000 \\
\hline Total RAI activity & $100 \mathrm{IQR}(55-167.5)$ & $532.5 \mathrm{IQR}(346.3-730)$ & $<0.001$ \\
\hline Number of applications & $1 \mathrm{IQR}(1-2)$ & $5.5 \mathrm{IQR}(2.8-6.8)$ & $<0.001$ \\
\hline Overall survival & $100 \%$ & $100 \%$ & - \\
\hline 5-year PFS & $86.8 \%$ & $83.3 \%$ & 0.631 \\
\hline
\end{tabular}

$\mathrm{PTC}=$ papillary thyroid cancer; $\mathrm{Tg}=$ thyroglobulin $; \mathrm{RAI}=$ radioiodine therapy; $\mathrm{PFS}=$ progression free survival; $\mathrm{IQR}=$ interquartile range

\section{Number of patients over time}

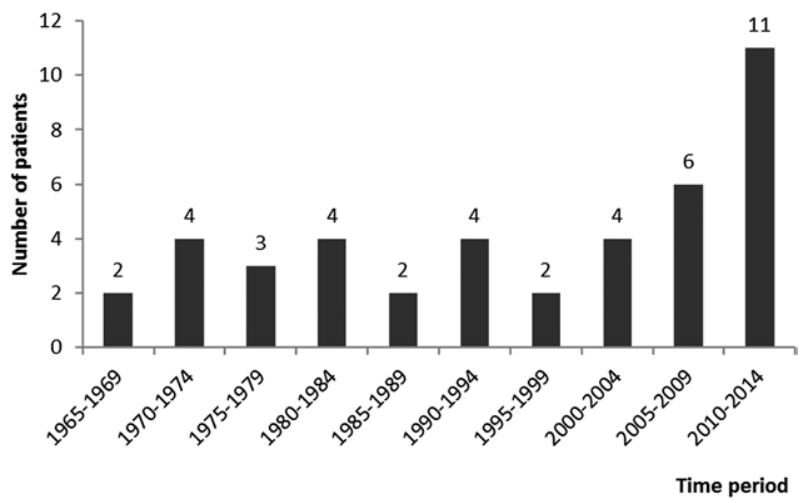

Fig. 1. The number of patients diagnosed with

differentiated thyroid cancer (DTC) was stable over time until the last decade, when a substantial increase in the number of newly diagnosed cases was observed. There was a significant positive trend of increase in the number of DTC patients over time. Time is shown in 5-year intervals.

\section{Tumor characteristics}

The median tumor size was $20.5 \mathrm{~mm}$ (IQR 11-28), and larger tumor size positively correlated with total I-131 activity (Rho 0.46, p=0.016) and number of $\mathrm{I}-131$ applications $(\mathrm{Rho}=0.046, \mathrm{p}=0.017)$. The pres-

\section{PFS by study period}

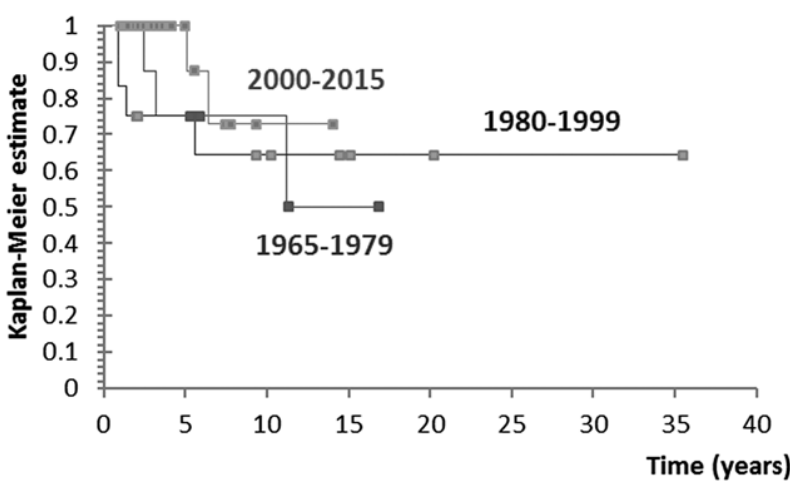

Fig. 2. Analysis of patients divided into tertiles of the study period.

$\mathrm{PFS}=$ progression free survival

ence of cervical lymph node metastasis (LNM) was significantly associated with papillary thyroid cancer (PTC) histology (66\% vs. 0\% for PTC and follicular thyroid cancer (FTC), respectively; $\mathrm{p}=0.022)$, larger tumor size $(26 \mathrm{~mm}$ vs. $15 \mathrm{~mm}$ for presence and absence of LNM; $\mathrm{p}=0.028$ ), involvement of two thyroid lobes ( $88 \%$ vs. $42 \%$ for bilobar and unilobar tumor, respectively; $\mathrm{p}=0.043)$ and multifocal tumor ( $89 \%$ vs. $42 \%$ for multi- and unifocal tumor, respectively; 
A

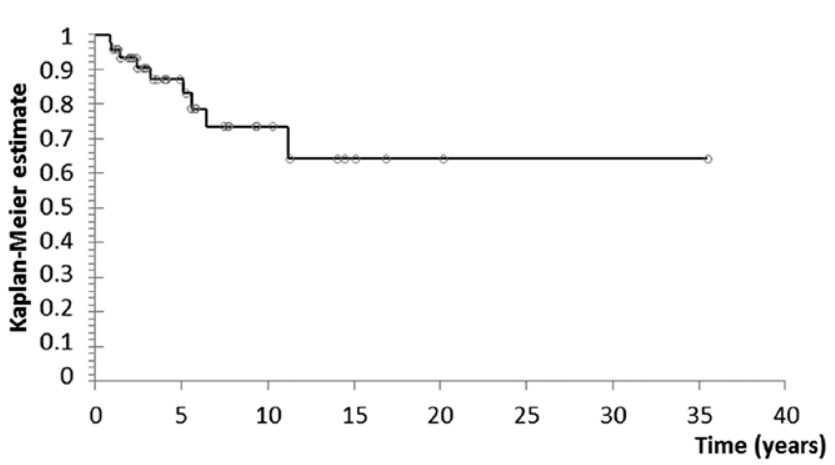

C

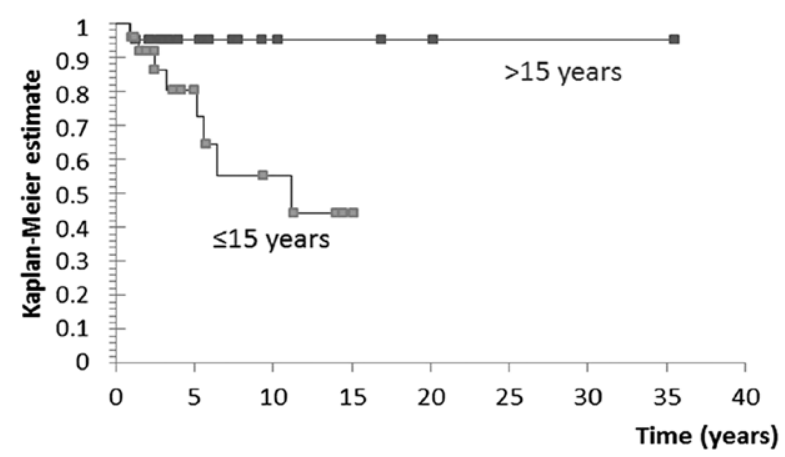

B

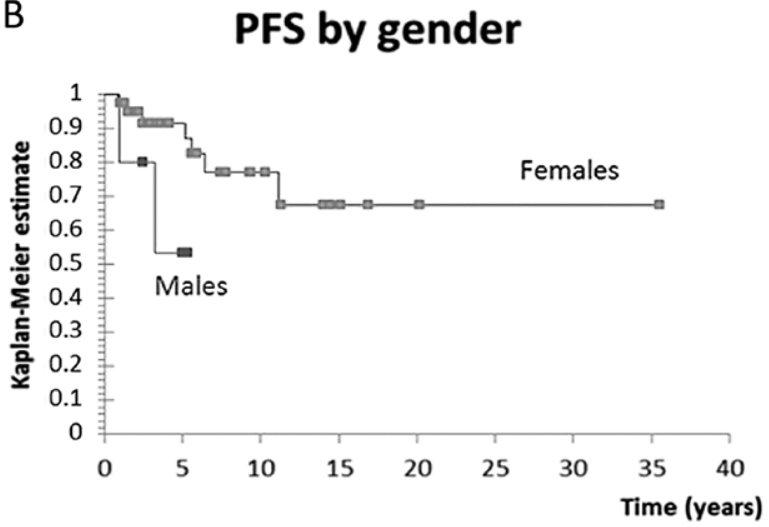

D

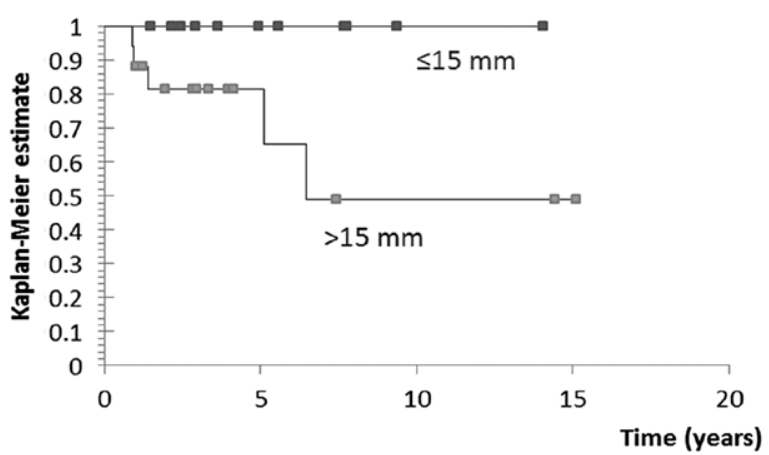

Fig. 3. (A) Progression free survival (PFS) curve for all patients; 5-year PFS was 87\%; (B) PFS curve by gender; male gender was significantly associated with inferior PFS (hazard ratio [HR] 4.22, $p=0.046$ ); (C) PFS by age; age $\leq 15$ years was significantly associated with inferior PFS (HR 7.18, $p=0.029)$; (D) PFS by tumor size; tumor size $>15 \mathrm{~mm}$ was significantly associated with inferior PFS (HR 6.29, $p=0.042)$.

$\mathrm{p}=0.039)$. A trend toward statistical significance was observed for association of LNM and presence of distant metastases ( $26 \%$ vs. $0 \%$ of patients for presence and absence of LNM, respectively; $\mathrm{p}=0.063$ ), as well as for association of LNM and higher total I-131 activity (5500 MBq [150 mCi] vs. $3700 \mathrm{MBq}$ [100 mCi] for presence and absence of LNM, respectively; $\mathrm{p}=0.064$ ). The presence of distant metastases was significantly associated with larger tumor size $(50 \mathrm{~mm}$ vs. $20 \mathrm{~mm}$ for presence and absence of distant metastases, respectively; $\mathrm{p}=0.002)$, higher total $\mathrm{I}-131$ activity (19720 $\mathrm{MBq}[533 \mathrm{mCi}]$ vs. $3700 \mathrm{MBq}[100 \mathrm{mCi}]$ for presence and absence of distant metastases, respectively; $\mathrm{p}<0.001)$ and higher number of I-131 activity applications (6 vs. 1 for presence and absence of distant metastases, respectively; $\mathrm{p}<0.001)$. Tumors infiltrating capsule were significantly larger in size (median 33 vs. $14 \mathrm{~mm}$ for infiltrating and non-infiltrating tumors, re- spectively; $p=0.01)$. No other significant associations were observed.

\section{Survival analyses}

The median follow-up of our cohort was 5.9 years. None of the patients died during the follow-up period. Five-year and 10-year OS rates were 100\% (median OS was not reached). No secondary malignancies were detected during follow-up, however, 9 relapses were observed. All relapsing patients experienced recurrence of disease in the neck, while three patients additionally had lung metastasis. Median PFS was not reached, with 5-year PFS rate of $87 \%$ and 10-year PFS rate of 73\%, as shown in Figure 3A. Male gender (hazard ratio [HR] 4.22, $\mathrm{p}=0.046$ ), age $\leq 15$ years (HR 7.18, $\mathrm{p}=0.029)$, and tumor size $>15 \mathrm{~mm}(\mathrm{HR} 6.29, \mathrm{p}=0.042)$ were significantly associated with inferior PFS, as shown in Figure 3B, Figure 3C, and Figure 3D, re- 
spectively. I-131 activity higher than $4366 \mathrm{MBq}(118$ $\mathrm{mCi}$ ) (HR 8.87, $\mathrm{p}=0.001$ ), and more than one I-131 application necessary for disease control in the setting of more advanced initial disease (HR 11.37, $\mathrm{p}=0.003$ ) were also associated with inferior PFS. There was no statistically significant effect of histopathologic diagnosis, capsule infiltration, number of tumor focuses, presence of cervical LNM, distant metastases or Tg level on PFS.

\section{Discussion}

Results of the present study indicated a worrying increasing trend in the number of new cases of pediatric DTC, with a substantial number of newly diagnosed cases in the last 10 years. The incidence of pediatric DTC appears to be increasing worldwide ${ }^{16}$. However, the observed increase in the number of cases during the last decade could have been due to the true rising incidence of pediatric DTC, but could also reflect other reasons (more patients referred to the institution, earlier diagnosis and detection of clinically less significant tumors). Analyses in this study were based on age cut-off of 18 years and were not directly comparable to the results of previously published studies that used different age cut-offs with the goal of defining a population of pediatric/young adult patients with DTC (17 to 30 years of age, mixed pre-pubertal, postpubertal and young adult population $)^{4,7-8,16-21}$. Larger tumors had significantly higher rates of LNM and distant metastases. Involvement of two thyroid lobes and multifocal tumor were also significantly linked with higher LNM rates, but the results were not statistically significant in relation to the initial presence of distant metastases. These results are in accordance with the study conducted by Kim et al., which found the increasing tumor size and multifocal disease to be independent factors associated with LNM in pediatric DTC $^{22}$.

In pediatric population, the goal of radiation is most commonly to eradicate known residual disease (micro-metastases), rather than to ablate the normal thyroid remnant only ${ }^{10}$. The increasing trend of I-131 application in patients under 25 years of age is reported, with percentages of patients receiving I-131 increasing from $4 \%$ in 1973 to $62 \%$ in 2008 . This phenomenon is present despite the increasing proportion of patients with low-risk features ${ }^{12}$. There are many data on I-131 use in thyroid cancer patients in adults $^{23-32}$. However, there are no randomized prospective clinical studies that address the issue of I-131 benefit in pediatric DTC population, dose-response relationship, or thyroid remnant ablation ${ }^{13}$. The benefit of I-131 in pediatric DTC was confirmed in the studies by Handkiewicz-Junak et al. and Chow et al. ${ }^{6,8}$. However, even patients with low-risk disease may still be at risk of residual cervical disease and they might also have indication for adjuvant I-131 therapy ${ }^{10}$.

The biggest concern in the application of multiple and high activities of I-131 is development of secondary malignancies. In a population-based analysis by Marti et al., which included patients aged $<25$ years, an increased risk of second malignancy was detected after I-131 therapy and it was slightly higher in children than in adult population ${ }^{12}$. The greatest risk of second primary malignancies occurs within 5 years of diagnosis and is higher in younger patients ${ }^{33}$. The threshold activity for the development of secondary malignancies is difficult to determine, however, some studies proposed cumulative activities of I-131 above 7400 $\mathrm{MBq}(200 \mathrm{mCi})$ and $11100 \mathrm{MBq}(300 \mathrm{mCi})^{13,34}$. The cumulative activities commonly administered to patients with distant metastases are usually much higher than the proposed thresholds. Regardless of the high cumulative activity, no secondary malignancies occurred in our cohort of patients.

As stated before, 9 relapses occurred in this cohort of patients. All patients experienced regional recurrence, and hematogenous dissemination to the lungs occurred in three patients. There were no distant metastases without lymph node involvement, with good 5 -year and 10 -year PFS rates of $87 \%$ and $73 \%$, respectively. This is in line with previously reported PFS rates that are considered to be much better than in adult patients ${ }^{6,8,35}$. Male gender, age 15 years or younger, and tumor size of more than $15 \mathrm{~mm}$ were significantly associated with inferior PFS in this cohort of patients. Although there was no significant difference in unfavorable disease features between genders or age groups, it has been previously reported that they may exist ${ }^{20}$. It is important to stress that significant association of larger I-131 activity and higher number of I-131 applications with inferior PFS is a consequence of more aggressive disease presentation mandating a more intensive approach, and should not be interpreted as a sign of therapy insufficiency/harm. The prognosis 
would probably be even worse if I-131 activity was reduced or omitted in these patients.

Limitations of our study were retrograde study design, small number of patients, incomplete number of observations for all patients, and long period of data collection (50 years). However, our observations represent a valuable contribution to the pool of knowledge about this rare tumor of pediatric age.

In conclusion, the incidence of pediatric thyroid cancer appears to be increasing worldwide, although it is not yet clear whether this is true increase or it is due to better detection of the disease. Male gender, age $\leq 15$ years, and tumor size $>15 \mathrm{~mm}$ were significantly associated with inferior PFS in this cohort of patients. All activities should be carried out in centers which employ a multidisciplinary team approach and have the necessary expertise in the management of pediatric thyroid cancer patients.

\section{References}

1. Howlader N, Noone AM, Krapcho M, Garshell J, Neyman N, Altekruse SF, et al. (eds). SEER Cancer Statistics Review, 1975-2013. National Cancer Institute. Bethesda, MD. Available at: http://seer.cancer.gov/csr/1975_2013/, based on November 2015 SEER data submission, posted to the SEER web site, April 2016.

2. Hogan AR, Zhuge Y, Perez EA, Koniaris LG, Lew JI, Sola JE. Pediatric thyroid carcinoma: incidence and outcomes in 1753 patients. J Surg Res. 2009;156:167-72. doi: 10.1016/j.jss.2009.03.100.

3. Cordioli MI, Moraes L, Cury AN, Cerutti JM. Are we really at the dawn of understanding sporadic pediatric thyroid carcinoma? Endocr Relat Cancer. 2015;22:R311-24. doi: 10.1530/ ERC-15-0381

4. Hay ID, Gonzalez-Losada T, Reinalda MS, Honetschlager JA, Richards ML, Thompson GB. Long-term outcome in 215 children and adolescents with papillary thyroid cancer treated during 1940 through 2008. World J Surg. 2010;34:1192-202. doi: 10.1007/s00268-009-0364-0.

5. Zimmerman D, Hay ID, Gough IR, Goellner JR, Ryan JJ, Grant CS, et al. Papillary thyroid carcinoma in children and adults: long-term follow-up of 1039 patients conservatively treated at one institution during three decades. Surgery. 1988; 104:1157-66.

6. Handkiewicz-Junak D, Wloch J, Roskosz J, Krajewska J, Kropinska A, Pomorski L, et al. Total thyroidectomy and adjuvant radioiodine treatment independently decrease locoregional recurrence risk in childhood and adolescent differentiated thyroid cancer. J Nucl Med. 2007;48:879-88. doi: 10.2967/ jnumed.106.035535
7. Welch Dinauer CA, Tuttle RM, Robie DK, McClellan DR, Svec RL, Adair C, et al. Clinical features associated with metastasis and recurrence of differentiated thyroid cancer in children, adolescents and young adults. Clin Endocrinol (Oxf). 1998; 49:619-28.

8. Chow SM, Law SC, Mendenhall WM, Au SK, Yau S, Mang $\mathrm{O}$, et al. Differentiated thyroid carcinoma in childhood and adolescence - clinical course and role of radioiodine. Pediatr Blood Cancer. 2004;42:176-83. doi: 10.1002/pbc. 10410

9. Leboulleux S, Baudin E, Hartl DW, Travagli JP, Schlumberger M. Follicular cell-derived thyroid cancer in children. Horm Res. 2005;63:145-51. doi: 10.1159/000084717

10. Francis GL, Waguespack SG, Bauer AJ, Angelos P, Benvenga $\mathrm{S}$, Cerutti JM, et al. American Thyroid Association Guidelines Task Force Management Guidelines for Children with Thyroid Nodules and Differentiated Thyroid Cancer. Thyroid. 2015; 25:716-59. doi: 10.1089/thy.2014.0460

11. The Canadian Pediatric Thyroid Nodule Study: an evaluation of current management practices. Canadian Pediatric Thyroid Nodule (CaPTN) Study Group. J Pediatr Surg. 2008;43: 826-30. doi: 10.1016/j.jpedsurg.2007.12.019.

12. Marti JL, Jain KS, Morris LG. Increased risk of second primary malignancy in pediatric and young adult patients treated with radioactive iodine for differentiated thyroid cancer. Thyroid. 2015;25:681-7. doi: 10.1089/thy.2015.0067.

13. Rivkees SA, Mazzaferri EL, Verburg FA, Reiners C, Luster M, Breuer CK, et al. The treatment of differentiated thyroid cancer in children: emphasis on surgical approach and radioactive iodine therapy. Endocr Rev. 2011;32:798-826. doi: 10.1210/er.2011-0011

14. Lucijanic M, Skelin M, Lucijanic T. Survival analysis, more than meets the eye. Biochem Med (Zagreb). 2017;27:14-8. doi: 10.11613/BM.2017.002

15. Lucijanic M. Survival analysis in clinical practice: analyze your own data using an Excel workbook. Croat Med J. 2016;57: 77-9. doi: $10.3325 / \mathrm{cmj} .2016 .57 .77$

16. Vergamini LB, Frazier AL, Abrantes FL, Ribeiro KB, Rodriguez-Galindo $\mathrm{C}$. Increase in the incidence of differentiated thyroid carcinoma in children, adolescents, and young adults: a population-based study. J Pediatr. 2014;164:1481-5. doi: 10.1016/j.jpeds.2014.01.059.

17. Lazar L, Lebenthal Y, Steinmetz A, Yackobovitch-Gavan M, Phillip M. Differentiated thyroid carcinoma in pediatric patients: comparison of presentation and course between prepubertal children and adolescents. J Pediatr. 2009;154:708-14. doi: 10.1016/j.jpeds.2008.11.059

18. Alzahrani AS, Alkhafaji D, Tuli M, Al-Hindi H, Bin Sadiq B. Comparison of differentiated thyroid cancer in children and adolescents ( $\leq 20$ years) with young adults. Clin Endocrinol (Oxf). 2015;84:571-7. doi: 10.1111/cen.12845

19. Verburg FA, Mader U, Luster M, Hanscheid H, Reiners C. Determinants of successful ablation and complete remission after total thyroidectomy and $131 \mathrm{I}$ therapy of paediatric dif- 
ferentiated thyroid cancer. Eur J Nucl Med Mol Imaging. 2015;42:1390-8. doi: 10.1007/s00259-015-3076-8

20. Markovina S, Grigsby PW, Schwarz JK, DeWees T, Moley JF, Siegel BA, et al. Treatment approach, surveillance, and outcome of well-differentiated thyroid cancer in childhood and adolescence. Thyroid. 2014;24:1121-6. doi: 10.1089/thy.2013.0297.

21. Kim SS, Kim SJ, Kim IJ, Kim BH, Jeon YK, Kim YK. Comparison of clinical outcomes in differentiated thyroid carcinoma between children and young adult patients. Clin Nucl Med. 2012;37:850-3. doi: 10.1097/RLU.0b013e318262c5d6.

22. Kim J, Sun Z, Adam MA Adibe OO, Rice HE, Roman SA, et al. Predictors of nodal metastasis in pediatric differentiated thyroid cancer. J Pediatr Surg. 2017;52:120-3. doi: 10.1016/j. jpedsurg.2016.10.033.

23. Franceschi M, Kusic Z, Franceschi D, Lukinac Lj, Rončević S. Thyroglobulin determination, neck ultrasonography and iodine-131 whole body scintigraphy in differentiated thyroid carcinoma.J Nucl Med. 1996;37:446-51.

24. Schlumberger M, Catargi B, Borget I, Deandreis D, Zerdoud S, Bridji B, et al. Tumeurs dela Thyroïde Refractaires Network for the Essai Stimulation Ablation Equivalence Trial. Strategies of radioiodine ablation in patients with low-risk thyroid cancer. N Engl J Med. 2012;366:1663-73. doi: 10.1056/NEJMoa1108586.

25. Mallick U, Harmer C, Yap B, Wadsley J, Clarke S, Moss L, et al. Ablation with low-dose radioiodine and thyrotropin alfa in thyroid cancer. N Engl J Med. 2012;366:1674-85. doi: 10.1056/NEJMoa1109589.

26. Ain KB. Radioiodine-remnant ablation in low-risk differentiated thyroid cancer: pros. Endocrine. 2015;50:61-6. doi: 10.1007/s12020-015-0668-9

27. Lamartina L, Cooper DS. Radioiodine remnant ablation in low-risk differentiated thyroid cancer: the "con" point of view. Endocrine. 2015;50:67-71. doi: 10.1007/s12020-014-0523-4.

28. Campennì A, Giovanella L, Pignata SA, Violi MA, Siracusa M, Alibrandi A, et al. Thyroid remnant ablation in differentiated thyroid cancer: searching for the most effective radioio- dine activity and stimulation strategy in a real-life scenario. Nucl Med Commun, 2015;36:1100-6.

doi: 10.1097/MNM.0000000000000367.

29. Prpic M, Dabelic N, Stanicic J, Jukic T, Milosevic M, Kusic Z. Adjuvant thyroid remnant ablation in patients with differentiated thyroid carcinoma confined to the thyroid: a comparison of ablation success with different activities of radioiodine (I-131). Ann Nucl Med. 2012;26:744-51. doi: 10.1007/s12149-012-0637-9.

30. Prpic M, Kruljac I, Kust D, Kirigin LS, Jukic T, Dabelic N, et al. Re-ablation I-131 activity does not predict treatment success in low- and intermediate-risk patients with differentiated thyroid carcinoma. Endocrine. 2016;52:602-8. doi: 10.1007/s12020015-0846-9

31. Prpic M, Kust D, Kruljac I, Kirigin LS, Jukic T, Dabelic N, et al. Prediction of radioactive iodine remnant ablation failure in patients with differentiated thyroid cancer: a cohort study of 740 patients. Head Neck. 2017;39:109-15. doi: 10.1002/hed.24550.

32. Haugen BR, Alexander EK, Bible KC, Doherty GM, Mandel SJ, Nikiforov YE, et al. American Thyroid Association management guidelines for adult patients with thyroid nodules and differentiated thyroid cancer: The American Thyroid Association (ATA) Guidelines Taskforce on thyroid nodules and differentiated thyroid cancer. Thyroid. 2016;26:1-133. doi: 10.1089/thy.2015.0020

33. Brown AP, Chen J, Hitchcock YJ, Szabo A, Shrieve DC, Tward JD. The risk of second primary malignancies up to three decades after the treatment of differentiated thyroid cancer.J Clin Endocrinol Metab. 2008;93:504-15. doi: 10.1210/jc.2007-1154

34. Rubino C, de Vathaire F, Dottorini ME, Hall P, Schvartz C, Couette JE, et al. Second primary malignancies in thyroid cancer patients. Br J Cancer. 2003;89:1638-44. doi: 10.1038/ sj.bjc. 6601319

35. Newman KD, Black T, Heller G, Azizkhan RG, Holcomb GW III, Sklar C, et al. Differentiated thyroid cancer: determinants of disease progression in patients $<21$ years of age at diagnosis: a report from the Surgical Discipline Committee of the Children’s Cancer Group. Ann Surg. 1998;227:533-41. 
Sažetak

\title{
DIFERENCIRANI KARCINOM ŠTITNJAČE U PEDIJATRIJSKOJ POPULACIJI ( $\leq 18$ GODINA): POSLIJEOPERACIJSKO LIJEČENJE RADIOAKTIVNIM JODOM (I-131)
}

\author{
M. Prpic, M. Franceschi, T. Jukić, D. Kust, N. Dabelic, T. Varjačic, M. Lucijanić, A. Bolanča i Z. Kusić
}

Cilj je prikazati podatke o liječenju i praćenju kohorte bolesnika s pedijatrijskim rakom štitnjače, kod kojih je učinjena totalna tireoidektomija te provedena poslijeoperacijska terapija radioaktivnim jodom (I-131). Studija je provedena u tercijarnom centru za štitnjaču visokog volumena, u bolesnika s pedijatrijskim diferenciranim karcinomom štitnjače koji su liječeni konsekutivno u razdoblju od 1965. do 2015. godine. U studiju je bilo uključeno 45 bolesnika (18 godina i mlađi) kod kojih je učinjena totalna tireoidektomija sa selektivnom disekcijom vrata ili bez nje. Odluka o indikaciji za provođenje poslijeoperacijske ablacije pomoću I-131 je donesena na temelju karakteristika tumora, poslijeoperacijske razine tireoglobulina, predablacijske scintigrafije cijelog tijela i/ili ultrazvuka vrata. Medijan dobi pri postavljanju dijagnoze je iznosio 15 godina. Prisutnost metastaza u limfne čvorove vrata je bila značajno povezana s papilarnim rakom štitnjače, većom veličinom tumora, zahvaćenosti dvaju režnjeva štitnjače te multifokalnom bolešću. Prisutnost udaljenih metastaza je bila značajno povezana s većom veličinom tumora. Tijekom razdoblja praćenja nijedan bolesnik nije preminuo, a 5-godišnje i 10-godišnje stope ukupnog preživljenja su iznosile 100\%. Petogodišnje i 10-godišnje preživljenje bez progresije bolesti (PPB) je iznosilo $87 \%$ odnosno $73 \%$. Muški spol $(\mathrm{p}=0,046)$, dob $\leq 15$ godina $(\mathrm{p}=0,029)$ i veličina tumora $>15 \mathrm{~mm}(\mathrm{p}=0,042)$ su bili značajno povezani s nižim PPB. Zamijećen je značajan trend porasta broja novodijagnosticiranih bolesnika tijekom vremena $(\mathrm{p}=0,011)$. Klinički postupak u populaciji dece s diferenciranim karcinomom štitnjače je izazovan, osobito u svjetlu porasta incidencije u ovoj populaciji. Osobitu pozornost treba posvetiti muškim bolesnicima mlađim od 15 godina s tumorima većim od $15 \mathrm{~mm}$ zbog opaženog nižeg PPB.

Ključne riječi: Jod; Karcinom štitnjače, papilarni; Adenokarcinom, folikularni; Stopa preživljenja; Dijete; Kontrolna istraživanja 